\title{
Simultaneous P-T-t estimation of ultrahigh-temperature high-pressure granulite facies metamorphism recorded in titanite
}

\author{
KENTA YOSHIDA ${ }^{1}$, SOTA NIKI ${ }^{2}$, HIKARU SAWADA ${ }^{1}$, \\ RYOSUKE OYANAGI ${ }^{1}$, TAKAFUMI HIRATA ${ }^{2}$, KENJI \\ ASAKURA $^{3}$ AND TAKAO HIRAJIMA ${ }^{3}$ \\ ${ }^{1}$ Japan Agency for Marine-earth Science and Technology \\ (JAMSTEC) \\ ${ }^{2}$ The University of Tokyo \\ ${ }^{3}$ Kyoto University \\ Presenting Author: yoshida_ken@jamstec.go.jp
}

The Sanbagawa metamorphic terrane in SW Japan records two distinct stages of metamorphism: the early stage of granulite to epidote-amphibolite facies with the age of Early Cretaceous (c. $120 \mathrm{Ma}$ ) and the later high-pressure metamorphism covering eclogite facies, so-called Sanbagawa metamorphism, with the age of Late Cretaceous. The early stage was recognized in coarse-grained mafic bodies in central Shikoku, whose protolith ages are Early Jurassic [1, 2].

We report the first evidence of the Early Jurassic metamorphic event preceding the above ones, based on the simultaneous pressure-temperature-time (P-T-t) estimation using titanite in a high-pressure marble collected from the Eastern Iratsu body of central Shikoku island. The studied sample records an eclogite facies stage of Late Cretaceous that was recovered by garnet petrochronology [3].

Titanite in the sample occurs in the matrix and inter-grain minerals within garnet-diopside aggregate (GDA). Matrix titanites show spindle shape while those in GDA show irregular shape. Back-scattered image observation yields most titanite are homogeneous (Ttn1) while some grains have thin dark rim (Ttn2). The formation P-T conditions of Ttn1 were well constrained by means of quartz-in-titanite Raman elastic barometer [4] and Zr-in-titanite thermometer [5], yielding 9001100 degreeC and 1.5-1.8 GPa. LA-ICP-MS U-Pb dating was performed for titanite and zircon. Zircon and Ttn1 yielded concordant age of Early Jurassic (200-180 Ma) while Ttn2 show a clear mixing line in the Terra-Wasserburg Concordia diagram whose lower intercept age was $126 \mathrm{Ma}$. The Early Cretaceous age of $\operatorname{Ttn} 2$ is comparable to that of the early Sanbagawa metamorphism although P-T conditions were not constrained. On the contrary, the Early Jurassic metamorphism of UHT-HP granulite conditions, much older and higher-conditions than previously recognized, have never been reported from the Sanbagawa metamorphic terrane.

[1] Endo, Wallis, Hirata, Anczkiewicz, Platt, Thirlwall \& Asahara (2009), JMG 31, 371-384. [2] Aoki, Aoki, Tsujimori, Sakata, \& Tsuchiya (2020), Lithos 358-359, 105378. [3] Niki, Yoshida, Sawada, Oyanagi \& Hirata (2020), Goldschmidt Virtual 2020, 1932. [4] Kohn (2014), EPSL 388, 187-196. [5] Hayden, Watson \& Wark (2008), CMP 155, 529-540. 